\title{
NEW GENUS OF AMPHICYONID CARNIVORAN (MAMMALIA, CARNIVORA, AMPHICYONIDAE) FROM THE PHOSPHORITES OF QUERCY (FRANCE)
}

\author{
LOUIS DE BONIS
}

Palevoprim: Laboratoire de Paléontologie, Evolution, Paléoécosystèmes, Paléoprimatologie, Bât B35 TSA51106 - 6 rue Michel Brunet, 86073 Poitiers cedex 9, France; e-mail: louis.debonis@univ-poitiers.fr.

Bonis, L. de (2020): New genus of amphicyonid carnivoran (Mammalia, Carnivora, Amphicyonidae) from the phosphorites of Quercy (France). - Fossil Imprint, 76(1): 201-208, Praha. ISSN 2533-4050 (print), ISSN 2533-4069 (on-line).

\begin{abstract}
An isolated mandible of Carnivora (Mammalia) from the phosphorites of Quercy (France) is described as a new genus. It is compared with the amphicyonid genus Cynodictis, some primitive North American amphicyonids, and with European and North American Eocene carnivoraforms. I conclude that it is a primitive amphicyonid which may be dated to the middle or late Eocene.
\end{abstract}

Key words: Eocene, Europe, North America, Carnivoraformes

Received: March 11, 2019 | Accepted: March 21, 2020 | Issued: November 9, 2020

\section{Introduction}

There is a large Jurassic limestone plateau in the French departments of Lot, Aveyron, and Tarn and Garonne. It emerged during the Cenozoic. During the middle of the Cenozoic it included a karstic system with a net of fissures, caves, and galleries that were filled by red clays containing a phosphatic sediment, the phosphorite. Discovered around 1866 by the chemist J. A. Pommarède, the phosphatic clays were worked in the last third of the $19^{\text {th }}$ century for the phosphorite which was used as fertiliser for fields. However, in the clays there were also thousands of fossils, especially the teeth and bones of vertebrates, which were collected by scientists and amateurs without taking into account the precise localities of the specimens. Thus, all the fossils were mixed up and it was impossible to date any bones, despite the great number of specimens scattered in private collections or in museums. Different studies (Gervais 1872, Filhol 1872a, b, 1873, 1874, 1876, 1877, 1882, Schlosser 1887, 1888, 1899, Gaillard 1908, Piveteau 1931, 1943, 1962, Ginsburg 1966, 1979, Bonis 1971, Springhorn 1977) concluded that the sediments were deposited over a large period of time from the middle Eocene to the late Oligocene.

Nevertheless, more recent studies showed that each site has a homogeneous fossil fauna which can be used to date the different localities (Gèze 1938a, b, Vianey-Liaud and Legendre 1986, Rémy et al. 1987, Biochrom'97 1997, Bonis et al. 1973, Bonis 1974, 1981, 2011, 2013) and the dating was extended from the late middle Eocene (Astruc et al. 2000) to the early Miocene (Sigé et al. 1991).
The order Carnivora is present among the fauna recorded in the phosphorites of Quercy (Filhol 1872a, b, 1873, 1874, 1876, 1877, 1882, Schlosser 1887, 1888, 1899, Teilhard de Chardin 1915, Piveteau 1931, 1943, 1962, Ginsburg 1966, 1979, Bonis 1966, 1971, 1974, 1978, 2011, 2019, Springhorn 1977) and there have been many publications on their species. Some of these carnivorans were revised by Teilhard de Chardin (1915). Among the new material described by Teilhard de Chardin, there was a small mandible which was considered as the holotype of a new species that he named Cynodon miacinus. Teilhard de Chardin was confused about the systematic position of the specimen. He noted that it displayed contradictory, primitive or derived, characters, but he finally linked it to the genus Cynodon Aymard, 1846, today Amphicynodon FiLhol, 1881 insofar as the name of Aymard (1846) was preoccupied by Cynodon SPIX, 1829, a fish genus. Nevertheless, there are many differences between Amphicynodon and the studied mandible. I decided to examine the specimen and to find a more precise systematic position.

\section{Material and methods}

The only referred material is a mandible housed in the MNHN, Paris, MNHN 1903-20, holotype (by monotypy) of the species "Cynodon" miacinus TeILHARD DE CHARdin, 1915.

The measurements were made by digital callipers to the nearest $0.01 \mathrm{~mm}$ and presented to the nearest $0.1 \mathrm{~mm}$. The material was compared with the old collections of Quercy which contain most of the types of specimens and with the 
fossils from other localities. The photographs were taken with a Nikon Coolpix 750 camera and processed with Adobe Photoshop.

We use capitals for the upper teeth and lower case for lower teeth.

\section{Abbreviations}

MNHN Muséum national d'Histoire naturelle, Paris, France pacd posterior accessory cuspid

\section{Systematic palaeontology}

\author{
Superorder Carnivoraformes Flynn, Finarelli \\ et Spaulding, 2010 \\ Order Carnivora Bowdich, 1821 \\ Suborder Caniformia KRetzoI, 1943 \\ Family Amphicyonidae Trouessart, 1885
}

\section{Storchictis n. gen.}

Type species. Cynodon miacinus TeILhard DE Chardin, 1915.

Origin of the name. Dedicated to Gerhard Storch for his numerous works on fossil vertebrates.

D i a g n o s is. See that of the type species.

\section{Storchictis miacinus (TeILHARd de ChaRdin, 1915)}

1915 Cynodon miacinus; Teilhard de Chardin, pp. 17-18, 53, pl. 1, fig. 8.

1965 «Amphicynodon » miacinus; Beaumont, p. 28.

H o l o ty pe. Hemimandible MNHN 1903-20 with p2, p4-m2 (Text-fig. 1).

Emended diagnosis. Smallest known European Amphicyonidae; gracile mandible, one mental foramen, top of ascending ramus semi-circular with an acute distally directed process, elongate angular process, $\mathrm{p} 2$ and $\mathrm{p} 4$ higher than the paraconid of $\mathrm{m} 1$ with a small basined talonid, large height difference between $\mathrm{m} 1$ protoconid and paraconid, the former relatively short, metaconid of $\mathrm{m} 1$ is well developed and higher than paraconid, deep V-shaped talonid valley of $\mathrm{m} 1$ with entoconid slightly higher than hypoconid, complete and relatively high trigonid of $\mathrm{m} 2$ with talonid similar to that of $\mathrm{m} 1$.

Differential diagnosis. Amphicynodon differs greatly from Storchictis by the presence of two mental foramina on the mandible, the rounded ascending ramus top, the thicker and low lower premolars, the thicker $\mathrm{m} 1$ with a lower trigonid with a smaller difference in height between the protoconid and paraconid and a basined talonid; in $\mathrm{m} 2$, the trigonid is low, the protoconid is equal to or smaller than the metaconid and the talonid is shallow and basined.

Cynodictis differs from Storchictis by the presence of two mental foramina on the mandible, the axe-shaped ascending ramus, the relatively lower $\mathrm{p} 2$ and $\mathrm{p} 4$, the longer mesio-distally protoconid of $\mathrm{m} 1$, the smaller difference in height between the protoconid and paraconid of $\mathrm{ml}$, the slightly lower trigonid of $\mathrm{m} 2$.
Type locality. Precise locality unknown, Quercy phosphorites, France.

Geological age. Unknown, possibly middle or late Eocene.

D e s c r i p t i o n. All the teeth are unworn except a small wear on the top of the paraconid of $\mathrm{m} 1$ which does not take on the height of the cuspid. The enamel has small pits due to weathering in the fossilisation process.

The mandible is small $(\mathrm{p} 2-\mathrm{m} 2=23 \mathrm{~mm}$; Teilhard de Chardin gives $39 \mathrm{~mm}$ for $\mathrm{i} 3-\mathrm{m} 3$ ) and bears $\mathrm{p} 2, \mathrm{p} 4-\mathrm{m} 2$ and alveoli of the canine, p1, p3, and $\mathrm{m} 3$, the latter being very small. The corpus is shallow, elongate, the lower border being convex from the cranial extremity to the level of the ascending ramus where it goes up and is slightly concave. There is only one mental foramen below the root of $\mathrm{p} 1$. The ascending ramus is high with a semi-rounded top and an acute distally pointed process. The masseter fossa is wide, extending cranially to $\mathrm{m} 3$, but not so deep; it is reinforced by a strong rim along the cranial border. The articular condyle is broad $(8.7 \mathrm{~mm})$ and below there is a well-developed angular caudal process which constitutes a good lever for the muscle pterigoideus medialis. The anterior part of the dentary tapers off and the symphysis is very oblique. The alveolus for $\mathrm{p} 1$ is oval and separated from the canine alveolus by about $2.6 \mathrm{~mm}$. After a small diastema $(1.4 \mathrm{~mm}), \mathrm{p} 2$ is higher than the paraconid of $\mathrm{m} 1$, sharp and bucco-lingually compressed; the crown is asymmetrical, the distal part being longer that the mesial one; there is a thin cristid along the mesial face and another one along the distal one; a cingulid surrounds the base and, distally, gives rise to a small talonid with a shallow minute basin. The $\mathrm{p} 4$, less asymmetrical than $\mathrm{p} 2$, is also higher than the paraconid of $\mathrm{m} 1$, pointed, and bucco-lingually compressed; there are also mesial and distal cristids, the latter with a trenchant, although step-like, posterior accessory cuspid. The step-like accessory cuspid is considered to be a derived amphicyonid feature (Tomiya and Tseng 2016). Here the cingulid forms a small mesial stylid and, distally, a slightly hollow talonid. The carnassial $\mathrm{m} 1$ is characterised by a great height difference between the protoconid and paraconid. The former displays a relatively short buccal face and an almost triangular basal section; the paraconid is far lower and moderately oblique relative to the sagittal plane. The metaconid is slightly higher than the paraconid and is nearly pyramidal with its almost flat buccal and distal faces while the lingual one is convex; it is not much reduced and it is not distally displaced, it does not appear in buccal view of the tooth and it closes the trigonid valley. The talonid is shaped by an entocristid that is slightly higher than the hypoconid, the latter being thicker with a cristid obliqua joining the middle of the base of the protoconid, and a V-shaped large valley; there is no trace of the hypoconulid and the valley is distally open. A cingulid surrounds the crown. The second molar is almost rectangular, although the talonid is slightly narrower than the trigonid (Tab. 1); the latter is complete and high relative to the talonid. The protoconid is higher, while the paraconid and metaconid are lower but well-developed, the former being a low ridge without pointed apex. The talonid is similar to that of $\mathrm{m} 1$ except for the cristid obliqua which is parallel to the sagittal plane. There is an oval alveolus for $\mathrm{m} 3$. 

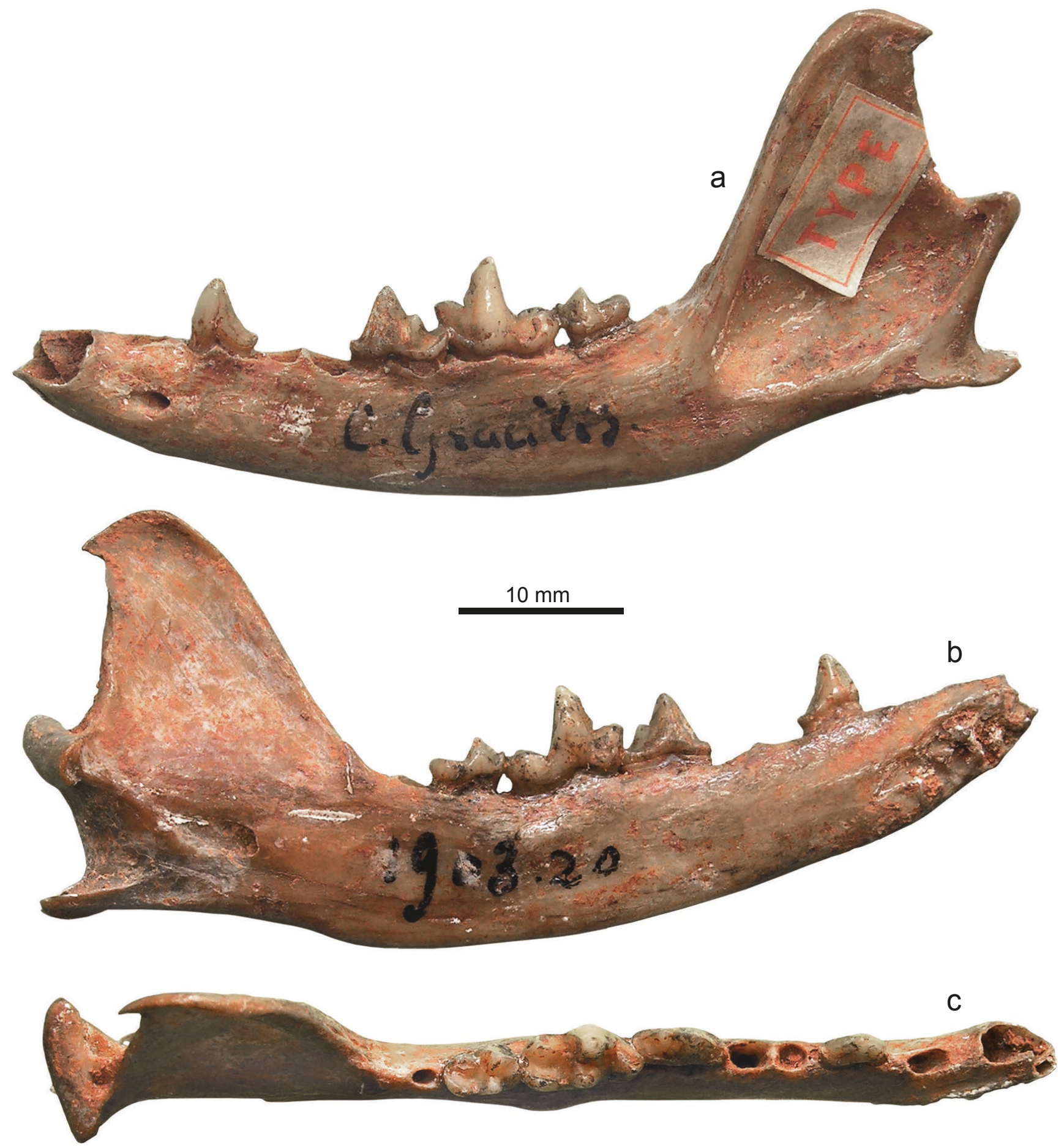

Text-fig. 1. Storchictis n. gen. miacinus (Teilhard de Chardin, 1915). Left hemimandible. a - buccal view, b - lingual view, $c-$ occlusal view. Scale bar $=10 \mathrm{~mm}$.

\section{Comparisons}

\section{Comparisons with Amphicynodon}

The generic name "Cynodon" (= Amphicynodon FILHOL, 1881) was used by Teilhard de Chardin (1915) and before him by Filhol who wrote "C. gracilis" on that mandible (see Text-fig. 1a and Teilhard de Chardin 1915: 117). However, the studied mandible is completely different from those of Amphicynodontidae. Amphicynodon gracilis for instance is a little larger, it has a relatively lower $\mathrm{m} 1$ trigonid with more inflated cuspids, simple and more inflated premolars with a more marked cingulid, p4 without pacd. The $\mathrm{m} 2$ is characterised by a low trigonid in which the metaconid is larger than the protoconid. Most of these characters are shared by all the Amphicynodontidae. Consequently, Storchictis n. gen. cannot be placed in this family. The affinities of Storchictis must be sought in the primitive amphicyonid genus Cynodictis BRAVARD et POMEL, 1850, or in the primitive Carnivoraformes.

\section{Comparisons with Cynodictis}

The type species, C. lacustris comes from the late Eocene locality La Débruge (Vaucluse, France). It was described by 
Table 1. Measurements of Storchictis miacinus compared to some Cynodictis species. L - length, w - width, tr - trigonid, tl - talonid, $\mathrm{n}$ - number of specimens, $\mathrm{m}$ - mean, $\mathrm{s}$ - standard deviation.

\begin{tabular}{|c|c|c|c|c|c|c|c|c|c|c|c|c|c|c|}
\hline Taxon & & p2 L & p2w & p3 L & p3 w & p4 L & p4 w & m1 L & m1 trL & m1 wtr & m1 wtl & $\mathrm{m} 2 \mathrm{~L}$ & m2 wtr & m2 wtl \\
\hline \multirow{2}{*}{ S. miacinus } & $\mathbf{n}$ & 1 & 1 & 1 & 1 & 1 & 1 & 1 & 1 & 1 & 1 & 1 & 1 & 1 \\
\hline & $\mathbf{m}$ & 3.9 & 1.9 & - & - & 5.9 & 2.5 & 7.5 & 4.25 & 4.2 & 3.4 & 4.4 & 2.8 & 2.5 \\
\hline \multirow{3}{*}{ C. lacustris neboulensis } & $\mathbf{n}$ & 3 & 3 & 7 & 7 & 15 & 15 & 24 & 24 & 24 & 24 & 29 & 29 & 14 \\
\hline & $\mathbf{m}$ & 4.1 & 2.4 & 5.9 & 2.7 & 6.9 & 3 & 9.2 & 5.96 & 4.6 & 4.98 & 5.0 & 3.5 & 3.1 \\
\hline & $\mathbf{s}$ & - & - & - & - & 0.43 & 0.14 & 0.52 & 0.49 & 0.29 & 0.42 & 0.33 & 0.22 & 0.37 \\
\hline \multirow{2}{*}{ C. longirostris } & $\mathbf{n}$ & 2 & 2 & 1 & 1 & 2 & 2 & 2 & 2 & 2 & 2 & 2 & 2 & 2 \\
\hline & $\mathbf{m}$ & 5.6 & 3.5 & 7.9 & 3.8 & 8.7 & 4.6 & 12.1 & 8.3 & 6.45 & 5.85 & 7.2 & 5.3 & 4.25 \\
\hline \multirow{2}{*}{ C. compressidens } & $\mathbf{n}$ & 1 & 1 & 1 & 1 & 2 & 2 & 2 & 2 & 1 & 2 & 2 & 2 & 2 \\
\hline & $\mathbf{m}$ & 3.7 & 2.6 & 5.3 & 3.5 & 7.2 & 3.8 & 9.8 & 6.4 & 5.3 & 4.55 & 5.35 & 3.75 & 3.6 \\
\hline \multirow{2}{*}{ C. lacustris lacustris } & $\mathbf{n}$ & - & - & - & - & 1 & 1 & 2 & 2 & 2 & 2 & 1 & 1 & 1 \\
\hline & $\mathbf{m}$ & - & - & - & - & 8.8 & 3.6 & 11 & 7.85 & 5.35 & 4.4 & 5.8 & 4.2 & 3.6 \\
\hline \multirow{2}{*}{ C. ferox } & $\mathbf{n}$ & - & - & 1 & 1 & 1 & 1 & 1 & 1 & 1 & 1 & 1 & 1 & 1 \\
\hline & $\mathbf{m}$ & - & - & 7.5 & 4.2 & 11.2 & 5.7 & 16.8 & 11.0 & 8.2 & 6.3 & 9.1 & 6.0 & 5.8 \\
\hline
\end{tabular}

Bravard and Pomel (1850) and published again by Gervais (1848-1852). Other species were described from the fossils coming from the phosphorites of Quercy and all are based on isolated mandibles insofar as the old collections were made without any precise locations. Until now, except for a few specimens from La Débruge, the sole population of the genus is that of Cynodictis lacustris neboulensis (Bonis 1978) from the Quercynian locality Sainte Néboule (MP 19). Its study was the opportunity of a short revision of the different species of Cynodictis by Bonis (1978) and then Kotsakis (1980) which was based on copies of the drawings.
Here, I shall only use the small or medium species which really belong to Cynodictis, whilst the others, particularly the largest forms, belong to other genera. Cynodictis lacustris (Bravard and Pomel 1850) has a thicker cingulid in p4. The $\mathrm{p} 4$ is lower relative to $\mathrm{m} 1$, and the height difference between the protoconid and paraconid of $\mathrm{m} 1$ is smaller. The trigonid valley between the paraconid and metaconid is more open, and the metaconid is slightly more distal and appears in buccal view. Cynodictis intermedius FILHOL, 1876, is close to C. l. lacustris and differs from Storchictis miacinus by the same characters and by the narrower talonid of $\mathrm{m} 2$. The same

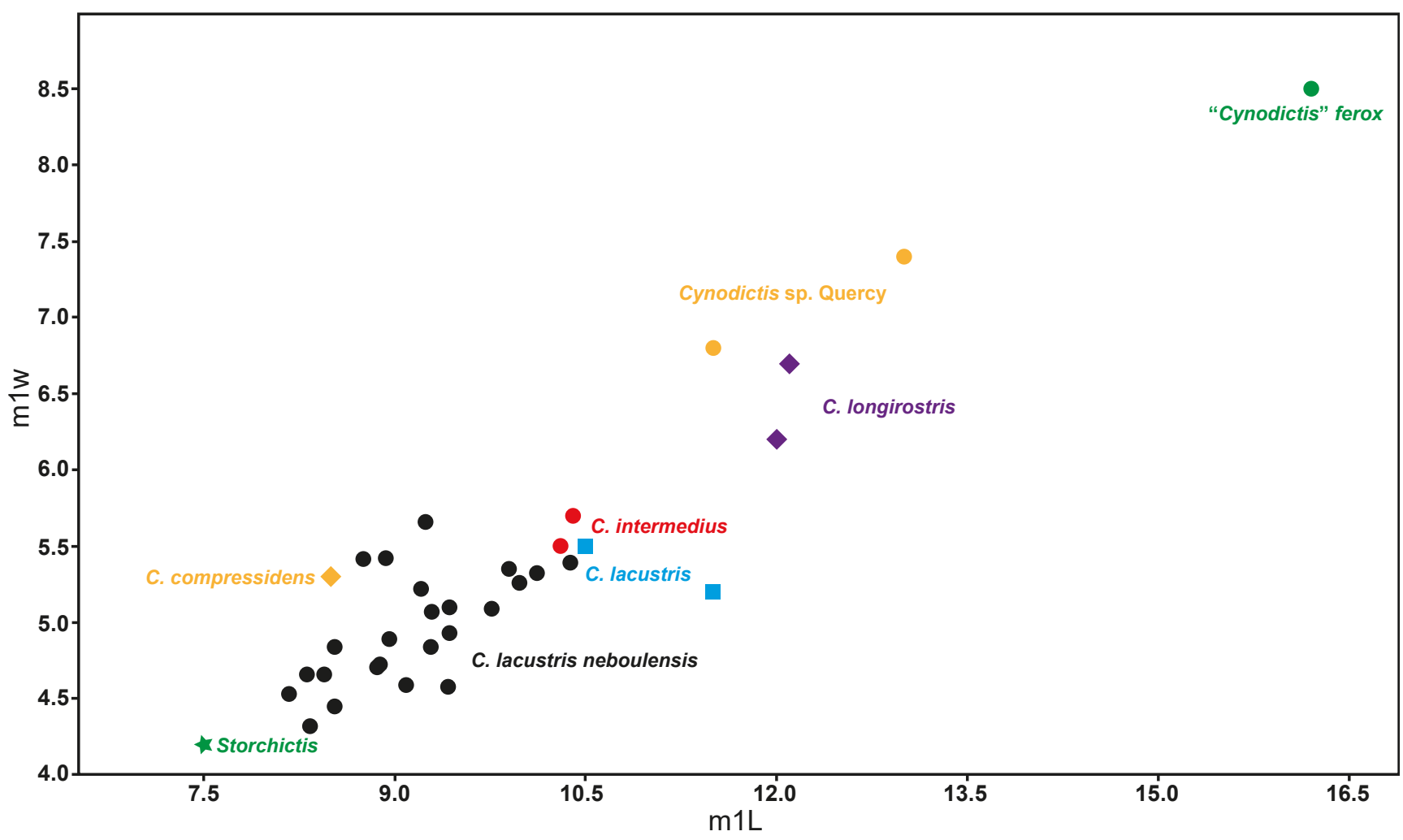

Text-fig. 2. Scatterplot of the $\mathrm{m} 1$ length versus $\mathrm{m} 1$ width in Storchictis compared to Cynodictis lacustris neboulensis (black dots) and other species of Cynodictis. 
can be said for $C$. intermedius viverroides and there is a lack of $\mathrm{m} 3$ as well. The Cynodictis longirostris FILHOL, 1872, and C. longirostris crassa TEILHARD DE CHARDIN, 1915, are larger than the preceding species and differ from $S$. miacinus by the same characters and also due to the relatively lower p2, the small entoconid of 1 and, especially for C. l. crassa, the long m2. Cynodictis compressidens FiLHOL, 1872, of which type specimen was lost, was used by Teilhard de Chardin (1915) for a mandible that is very close to that of $C$. intermedius and different from the mandible shown by Filhol (1872b: pl. 16, figs 28-30). Nevertheless, Teilhard de Chardin figured other mandibles such as C. compressidens exilis which seem similar to the Filhol's specimen. I proposed (Bonis 1978) the mandible MNHN QU 8889 can be considered as the type specimen of Cynodictis exilis TeILHARD DE CHARdin, 1915. The latter, small species of Cynodictis, differs from Storchictis n. gen. due to its a larger size, more robust $\mathrm{p} 4$ and $\mathrm{m} 1$, a smaller height difference between the protoconid and paraconid of $\mathrm{m} 1$, the paraconid is more oblique relative to the sagittal plane and low entoconid of $\mathrm{m} 1, \mathrm{~m} 2$ without a clear paraconid, and a narrow talonid without a clear entoconid. A glimpse at the C. lacustris neboulensis sample, the bestknown of the genus, shows the same result. The subspecies differs from Storchictis due to its larger size (Text-fig. 2), the lower premolars that are not as high, the presence of a small posterior accessory cuspid on $\mathrm{p} 2$, the smaller difference in height between the paraconid and protoconid of $\mathrm{m} 1$, and the slightly more elongate protoconid of $\mathrm{m} 1$, both of the last characters being derived; $\mathrm{m} 2$ has a slightly lower protoconid. In conclusion, Storchictis cannot belong to Cynodictis, due to some of its characters being more primitive such as the tall premolars, the large height difference between the paraconid and protoconid of $\mathrm{ml}$, the latter of which has a narrower mesio-distal diameter, the more developed metaconid, and the well-developed and pointed paraconid of $\mathrm{m} 2$.

\section{Comparisons with the "Miacidae"}

The name "miacinus" that was given by Teilhard de Chardin to that species indicates that he thought that the mandible had affinities with the family "Miacidae", which at the time was considered to be a stem group of Carnivora (Piveteau 1961) but nowadays is considered polyphyletic. That family was built around the genus Miacis Cope, 1872 (Cope 1880) which was recorded in North America and in Eurasia (M. sylvestris MARsh, 1872, M. vulpinus SCOTT et Osborn, 1887, M. uitensis OsBorn, 1895 in North America; M. invictus Matthews et Granger, 1925, M. thailandicus Ducroce et al., 1992 in Asia; M. rundlei Hooker, 2010 and Miacis exilis FILHOL, 1877 in Europe).

Nowadays, the data challenge that point of view, and "Miacis represents perhaps one of the most confused genera in the classification of early carnivoraforms, with at least 19 species having been assigned to the genus" (Tomiya and Tseng 2016). In recent attempts to reconstruct carnivoraform phylogeny, the "Miacis" species are scattered in different branches of the cladograms (Wesley-Hunt and Flynn 2005, Flynn et al. 2010, Spaulding et al. 2010, Solé 2014, Solé et al. 2014).

I shall examine some European species first and then some North American ones. Quercygale angustidens
(FILHOL, 1872) was first considered to be a miacid. A review of its relationships (Wesley-Hunt and Werdelin 2005) led to the conclusion that it was the sister group of the clade consisting of Nimravidae and Carnivora. However, in any case, it is very different from Storchictis n. gen. not only due to its larger size but especially due to the shape of the symphysis angle that is close to $90^{\circ}$ (Teilhard de Chardin 1915: pl. I, fig. 12), the marked flange, the relatively lower $\mathrm{p} 4$, the smaller height difference between the paraconid and protoconid of $\mathrm{ml}$, the shorter protoconid, the shorter and trenchant talonid, and the absence of $\mathrm{m} 3$. Most of the Quercygale specimens come from the old phosphorites of the Quercy collections but others were recorded elsewhere in late Eocene layers. Another species, Quercygale smithi SolÉ, 2014 was recorded in European early Eocene layers.

Miacis was also described in Europe from remains from the old Quercy collections under the name Cynodictis exilis FILHOL, 1876 but later under Miacis exilis (Teilhard de Chardin 1915, Guth 1964) and, after revision, Paramiacis exilis (FILHOL, 1876) by Mathis (1985, 1987). The latter also described another Quercynian species, Paramiacis teilhardi MATHIS, 1987. Both species were also recorded and dated in the stratigraphy and in the Quercy fissure fillings of the new Quercynian excavations (Matthis 1985, 1987). These species are smaller and differ from Storchictis by the simple premolars ( $\mathrm{p} 4$ without posterior accessory cuspid) with robust cingulids, the trigonid of $\mathrm{m} 1$ with more closely positioned cuspids, a higher and shorter paraconid, a higher contact between the paraconid and metaconid, a more robust hypoconid, and a higher trigonid of $\mathrm{m} 2$. These characters may be considered as plesiomorphic features that are present in most of the Eocene carnivoraforms and sometimes are more clearly expressed, see for instance Gracilocyon solei Sмiтн et Sмiтh, 2009, from the earliest Eocene (Smith and Smith 2009).

It is known that there is a diverse array of early carnivoraforms in North America. The genus Miacis was split into several species. The type-species Miacis parvivorus COPE, 1872, differs from Storchictis due to the simple premolars, particularly $\mathrm{p} 4$ which is lacking posterior accessory cuspid, a case which seems to be common in "miacids" where the p4 posterior accessory cuspid is absent or small and lowly situated (Matthew 1909: 347), the very high trigonid with closely positioned cuspids, the height of the closure of the trigonid valley by the contact of paraconidmetaconid, the very high $\mathrm{m} 2$ trigonid, and the clear cuspids of $\mathrm{m} 3$. Miacis was reported from the early Chadronian (early Oligocene) of Texas (Gustafson 1986) with a couple of "miacid" species Miacis cognitus GuSTAFson, 1986, and M. australis GUSTAFSON, 1986. However, recently another study of the fossils led to a different result (Tomiya and Tseng 2016). The fossils were dated by radiochronology to about $38 \mathrm{Ma}$, late Middle Eocene (equivalent of European Bartonian). A cladistics analysis situated the two species in a clade with the European genus Cynodictis, thus as two amphicyonid representatives and both species were considered to be type-species of new genera: Gustafsonia cognita (GUSTAFson, 1986) and Angelarctocyon australis (GUSTAFSON, 1986). The mandible of the former is unknown but that of the latter is known (Gustafson 1986: fig. 29, Tomiya and Tseng 2016: fig. 4). A. australis, whose size 
is very close to that of Storchictis (both $\mathrm{m} 1 \mathrm{~L}=7.5 \mathrm{~mm}$ ), differs from the Quercynian fossil by two mental foramina, p4 without mesial stylid and a shorter talonid, $\mathrm{m} 1$ with a smaller height difference between the protoconid and paraconid, a more open trigonid, the metaconid appearing slightly in buccal view (Gustafson 1986: fig. 29, Tomiya and Tseng 2016: fig. 4), and a slightly more elongate protoconid, derived characters, while both $\mathrm{m} 2$ seem to be similar but the paraconid of $A$. australis is more pointed and the trigonid is more closed, a plesiomorphic character.

\section{Conclusion}

The basis of the Carnivora systematics are founded on the structures of the skull, especially those of the ear region (Flower 1869). All the recent reappraisals of the classification essentially used the features derived from the skull. Presently, as is frequent in mammalian palaeontology, there is no a large data set to study the mandible of Storchictis. We have to compare our fossil to the taxa of which the skull characters are known and allows us to determine the precise position in relation to their mandibles. Storchictis, when compared to Cynodictis, may be considered on the one hand as slightly more primitive due to some features, such as the shape of the $\mathrm{m} 1$ trigonid and the shape of $\mathrm{m} 2$. On the other hand, it is more derived than the non-carnivoran carnivoraforms. In other words, it seems to be closer to the case of taxa such as Angelarctocyon australis whose skull anatomy indicates amphicyonid affinities (Tomiya and Tseng 2016). Thus, Storchictis displays some features (less "miacid" like trigonid of $\mathrm{m} 1$ with less close-positioned cuspids and more elongated paraconid, shorter $\mathrm{m} 2$ trigonid) which indicate a trend towards a Cynodictis-like anatomy, therefore towards the family Amphicyonidae.

The geologic age of Storchictis n. gen. is difficult to estimate. The ages of the phosphorites from Quercy span a large range. Until now the oldest fossils ever found in the phosphorites are dated to middle Eocene (Astruc et al. 2000). The youngest locality is Crémat, dated to early Miocene (Sigé et al. 1991). During that time there were several changes in the European mammal fauna. The most significant is called "Grande Coupure" of the Tertiary (Stehlin 1909) and was considered as the limit between the Eocene and Oligocene. In terms of mammal Paleogene reference-levels (MP), it is between MP 20 and MP 21. Nevertheless, the faunas from the same type of localities are not homogeneous and sometimes taxa could be absent for taphonomic reasons. However, we see that primitive carnivoraforms did not cross the "Grande Coupure". Quercygale is found in MP 16 to MP 17 in the Quercy, such as Paramiacis Mathis, 1985. Likewise, Cynodictis is only present in the Quercy in MP 18 and MP 19. Yet, the younger specimens, such as "Cynodictis" palmidens from Aubrelong 1 (MP 21), which is not a Cynodictis (LangeBadré 2006) have different features. For example, the two specimen holotypes of " $C$ ". palmidens and " $C$ ". palmidens major display a drastic reduction of the metaconid of $\mathrm{m} 1$ and a shortening of $\mathrm{m} 2$, thus indicating a different lineage with a more cutting dentition and the affinities of which have to be determined (Bonis 1978: 308). It has been suggested that other specimens recorded from other sites, notably in Asia, belong to the genus Cynodictis. However, these attributions are probably invalid as has been shown or discussed by several authors (Bonis 1978, Kotsakis 1980, Hunt 1998, Lange-Badré 2006, Egi et al. 2009, Tomiya and Tseng 2016). After the limit of the "Grande Coupure", it seems that Cynodictis and the primitive carnivoraforms were replaced by new migrants such as the fore runner nimravids, Amphicynodontidae, Cephalogalini, Palaeogale, Felidae, and primitive mustelids. Thus, we may speculate that Storchictis n. gen. was possibly present in the European middle or late Eocene.

\section{Acknowledgements}

The redaction of that article profited by the staff of PALEVOPRIM University of Poitiers and especially Sabine Riffaut for the work on the figures with Adobe Photoshop. It was made possible by the kindness of Dr. Christine Argot, in charge of the fossil collections in the MNHN. I thank a lot the editors, Floreal Solé and an anonymous reviewer for their comments which greatly improved the manuscript. The English language corrections are due to ProofReadingService.

\section{References}

Astruc, J.-G., Escarguel, G., Marandat, B., Simon-Coinçon, R., Sigé, B. (2000): Floor-age constraining of a tectonic paroxysm of the Pyrenean orogen. Late middle Eocene mammal age of a faulted karstic filling of the Quercy phosphorites, south-western France. - Geodinamica Acta, 13(5): 271-280.

https://doi.org/10.1016/S0985-3111(00)01047-0

Aymard, A. (1846): Essai monographique sur un nouveau genre de mammifère fossile trouvé dans la haute vallée de la Loire et nommé Entelodon. - Annales de la Société d'Agriculture du Puy, 12: 227-267.

Beaumont, G. de (1965): Contribution à l'étude du genre Cephalogale Jourdan (Carnivora). - Mémoires suisses de Paléontologie, 82: 1-34.

Biochrom'97 (1997): Synthèses et tableaux de corrélations in Acts of the Congress Biochrom'97. - Mémoires et travaux de l'EPHE, 21: 769-805.

Bonis, L. de (1966): Arrières-crânes et moulages endocrâniens de Carnivores fossiles. - Annales de Paléontologie, Vertébrés, 52(2): 143-162.

Bonis, L. de (1971): Deux nouveaux carnassiers des Phosphorites du Quercy. - Annales de Paléontologie, Vertébrés, 57(1): 117-127.

Bonis, L. de (1974): Premières données sur les carnivores fissipèdes provenant des fouilles récentes dans le Quercy. - Palaeovertebrata, 6: 27-32.

Bonis, L. de (1978): La poche à phosphate de Sainte Néboule (Lot) et sa faune de vertébrés du Ludien supérieur. 12 - Fissipèdes (Carnivores). - Palaeovertebrata, 8(2-4): 301-311.

Bonis, L. de (1981): Contribution à l'étude du genre $\mathrm{Pa}$ laeogale Meyer (Mammalia, Carnivora). - Annales de Paléontologie, Vertébrés, 67(1): 37-56.

Bonis, L. de (2011): A new species of Adelpharctos (Mammalia, Carnivora, Ursidae) from the late Oligocene 
of the "Phosphorites du Quercy" (France). - Estudios Geológicos, 67(2): 179-186.

https://doi.org/10.3989/egeol.40553.181

Bonis, L. de (2013): Ursidae (Mammalia, Carnivora) from the late Oligocene of the 'Phosphorites du Quercy' (France) and a reappraisal of the genus Cephalogale. Geodiversitas, 35(4):747-814.

https://doi.org/10.5252/g2013n4a4

Bonis, L. de, Crochet, J. Y., Rage, J. C., Sigé, B., Sudre, J., Vianey-Liaud, M. (1973): Nouvelles faunes de vertébrés oligocènes des Phosphorites du Quercy. - Bulletin du Muséum national d'Histoire naturelle, ser. $3^{\circ}$ (no. 174), Sciences de la terre, 28: 105-113.

Bonis, L. de, Gardin, A., Blondel C. (2019): Carnivora of the early Oligocene of the 'Phosphorites du Quercy' in southwestern France. - Geodiversitas, 41(15): 601-621. https://doi.org/10.5252/geodiversitas2019v41a15

Bravard, A., Pomel, N. A. (1850): Notice sur les ossements fossils de La Débruge près Apt. - Impr. J.-S. Jean, Apt (France), 8 pp.

Cope, E. D. (1872): Third account of new Vertebrata from the Bridger Eocene of Wyoming territory. - Paleontological Bulletin, no. 3: 1-4. [reprinted in Proceedings of the American Philosophical Society, 12: 469-472 (1873)]

Cope, E. D. (1880): On the genera of the Creodonta. Proceedings of the American Philosophical Society, 19(107): 76-82.

Egi, N., Tsubamoto, T., Tsogtbaatar, K. (2009): New amphicyonid (Mammalia: Carnivora) from the Upper Eocene Ergilin Dzo Formation, Mongolia. - Palaeontological Research, 13(3): 245-249. https://doi.org/10.2517/1342-8144-13.3.245

Filhol, H. (1872a): Sur les Carnassiers et les Chéiroptères dont on trouve les débris fossiles dans les gisements de phosphorites de Caylus, Frégols, Concots. - Comptes Rendus hebdomadaires des séances de l'Académie des Sciences, Paris, 75: 92-94.

Filhol, H. (1872b): Recherches sur les mammifères fossiles des dépôts de phosphate de chaux dans les départements du Lot, du Tarn, et de Tarn-et-Garonne. Première partie: carnassiers et chiroptères. - Annales des Sciences géologiques, 3(7): 1-31.

Filhol, H. (1873): Sur les vertébrés fossiles trouvés dans les dépôts de phosphate de chaux du Quercy. - Bulletin de la Société philomathique de Paris, Sér. 6, 10: 85-89.

Filhol, H. (1874): Sur les mammifères fossiles trouvés dans les dépôts de phosphates de chaux du Quercy. - Bulletin de la Société philomatique de Paris, Sér. 6, 11: 16-20.

Filhol, H. (1876): Recherches sur les phosphorites du Quercy. Étude des fossiles qu'on y rencontre et spécialement des mammifères. - Bibliothèque de l'École des hautes études, Section des sciences naturelles, 15(art. no. 4): 1-220. [published also in Annales des sciences géologiques, 7(art. no. 7): 1-220]

Filhol, H. (1877): Recherches sur les phosphorites du Quercy. Étude des fossiles qu'on y rencontre et spécialement des mammifères. - Bibliothèque de l'École des hautes études, Section des sciences naturelles, 16(art. no. 1): 1-338. [published also in Annales des sciences géologiques, 8(art. no. 1): 1-340]
Filhol, H. (1882): Mémoires sur quelques mammifères fossiles des phosphorites du Quercy. -Impr. Vialelle et Cie, Toulouse, $140 \mathrm{pp}$.

https://doi.org/10.5962/bhl.title.86309

Flower, W. H. (1869): On the value of the characters of the base of cranium on the classification of the order Carnivora, and on the systematic position of Bassaris and other disputed forms. - Proceedings of the Zoological Society of London, 1869: 4-37. https://doi.org/10.1111/j.1469-7998.1869.tb07286.x

Flynn, J. J., Finarelli, J., Spaulding, M. (2010): Phylogeny of the Carnivora and Carnivoramorpha, and the use of the fossil record to enhance understanding of evolutionary transformations. - In: Goswani, A., Friscia, A. R. (eds), Carnivoran evolution: new views on phylogeny, form and function. Cambridge University Press, Cambridge, pp. 25-63. https://doi.org/10.1017/CBO9781139193436.003

Gaillard, C. (1908): Les oiseaux des phosphorites du Quercy. - Annales de l'Université de Lyon, Nouvelle série, 1. Sciences, médecine, 23: 1-178.

Gervais, P. (1848-1852): Zoologie et paléontologie française. - Arthus Bertrand, Paris, 269 pp.

Gervais, P. (1872): Sur les mammifères dont les ossements accompagnent les dépôts de chaux phosphatée des départements de Tarn et Garonne et du Lot. - Journal de Zoologie, Paris, 1: 261-268.

Gèze, B. (1938a): Contribution à la connaissance des Phosphorites du Quercy. - Bulletin de la Société Géologique de France, Paris, 5(8): 123-146.

Gèze, B. (1938b): La genèse des Phosphorites du Quercy. - Comptes rendus hebdomadaires des séances de l'Académie des Sciences, Paris, 206: 759-761.

Ginsburg, L. (1966): Les Amphicyons des Phosphorites du Quercy. - Annales de Paléontologie, Vertébrés, 52(1): 23-44.

Ginsburg, L. (1979): Révision taxonomique des Nimravini (Carnivora, Felidae) de l'Oligocène des Phosphorites du Quercy. - Bulletin du Muséum national d'Histoire naturelle, Paris, 4(1): 35-49.

Gustafson, E. P. (1986): Carnivorous mammals of the late Eocene and early Oligocene of Trans-Pecos Texas. Texas Memorial Museum Bulletin, 33: i-v + 1-66.

Guth, C. (1964): A propos de Miacis exilis des phosphorites du Quercy. - Mammalia, 28(2): 359-365. https://doi.org/10.1515/mamm.1964.28.2.359

Hunt, R. Jr. (1998): Evolution of the Aeluroid Carnivora: Diversity of the Earliest Aeluroids from Eurasia (Quercy, Hsanda-Gol) and the origin of Felids. - American Museum Novitates, 3262: 1-65.

Kotsakis, T. (1980): Revisione sistematica e distribuzione stratigrafica e geografica del genre Cynodictis Bravard \& Pomel (Carnivora, Mammalia) [Systematic revision and stratigraphic and geographic distribution of the genus Cynodictis Bravard \& Pomel (Carnivora, Mammalian)]. - Bollettino della Società Paleontologica Italiana, 19(2): 259-273. (in Italian)

Lange-Badré, B. (2006): Quelques caractères morphofonctionnels du membre antérieur des petits mammifères carnivores d'Aubrelong 1 (Oligocène inférieur, Lot, France). - Strata, 1(13): 103-112. 
Mathis, C. (1985): Contribution à la connaissance des mammifères de Robiac (Éocène supérieur): Creodonta et Carnivora. - Bulletin du Muséum national d'Histoire naturelle, section C, 4e Ser., 7(4): 305-326.

Mathis, C. (1987) Précisions sur le genre Paramiacis Mathis (Carnivora, Miacidae). - Bulletin du Muséum national d'Histoire naturelle, section C, 4e Ser., 9(3): 313-326.

Matthew, W. D. (1909): The Carnivora and Insectivora of the Bridger Basin, middle Eocene. - Memoirs of the American Museum of Natural History, 9(6): 191-576.

Piveteau, J. (1931): Les chats des Phosphorites du Quercy. Annales de Paléontologie, 20: 107-163.

Piveteau, J. (1943): Etudes sur quelques mammifères des Phosphorites du Quercy. I. Le genre Stenoplesictis. Annales de Paléontologie, 30: 63-72.

Piveteau, J. (1961): Carnivora. - In: Piveteau, J. (ed.), Traité de Paléontologie, T. VI, Vol. 1. Masson, Paris, pp. 641-802.

Piveteau, J. (1962): L'encéphale de Viverravus angustidens, Miacidé des Phosphorites du Quercy. - Annales de Paléontologie, 48: 45-75.

Rémy, J. A., Crochet, J.-Y., Sigé, B., Sudre, J., Bonis, L. de, Vianey-Liaud, M., Godinot, M., Hartenberger, J.-L., Lange-Badré, B., Comte, B. (1987): Biochronologie des phosphorites du Quercy: mise à jour des listes fauniques et nouveaux gisements de mammifères fossiles. Münchner Geowissenschaftliche Abhandlungen, A, 10: 169-188.

Schlosser, M. (1887): Die Affen, Lemuren, Chiropteren, Insectivoren, Marsupialier, Creodonten und Carnivoren des europäischen Tertiärs und deren Beziehungen $\mathrm{zu}$ ihren lebenden und fossilen aussereuropäischen Verwandten. I. Theil. - Beiträge zur Paläontologie Österreich-Ungarns und des Orients, 6: 1-224.

Schlosser, M. (1888): Die Affen, Lemuren, Chiropteren, Insectivoren, Marsupialier, Creodonten und Carnivoren des europäischen Tertiärs und deren Beziehungen $\mathrm{zu}$ ihren lebenden und fossilen aussereuropäischen Verwandten. II Theil. - Beiträge zur Paläontologie Österreich-Ungarns und des Orients, 7: 1-162.

Schlosser, M. (1899): Ueber die Bären und bärenähnlichen Formen des europäischen Tertiärs. - Palaeontographica, 46(4): 95-148.

Sigé, B., Aguilar, J. P., Marandat, B. (1991): Extension au Miocène inférieur des remplissages phosphatés du Quercy, la faune de vertébrés de Crémat (Lot, France). - Geobios, 23(4): 497-502. https://doi.org/10.1016/S0016-6995(06)80251-2

Smith, T., Smith, R. (2009): A new 'miacid' carnivoran from the earliest Eocene of Europe and North America. - Acta Palaeontologica Polonica, 55(4): 761-764.

https://doi.org/10.4202/app.2009.0125
Solé, F. (2014): New carnivoraforms from the early Eocene of Europe and their bearing on the evolution of the carnivore forms. - Palaeontology, 57: 963-978. https://doi.org/10.1111/pala.12097

Solé, F., Smith, R., Coillot, T., Bast E. de, Smith, T. (2014): Dental and tarsal anatomy of "Miacis" latouri and a phylogenetic analysis of the earliest carnivoraforms (Mammalia, Carnivoramorpha). - Journal of Vertebrate Paleontology, 34(1): 1-21. https://doi.org/10.1080/02724634.2013.793195

Spaulding, M., Flynn, J. J., Stucky, R. K. (2010): A new basal Carnivoramorphan (Mammalia) from the 'Bridger B' (Black's Fork member, Bridger Formation, Bridgerian Nalma, middle Eocene) of Wyoming, USA. - Palaeontology, 53(4): 815-832. https://doi.org/10.1111/j.1475-4983.2010.00963.x

Springhorn, R. (1977): Revision der alttertiären europäischen Amphicyonidae (Carnivora, Mammalia). - Palaeontographica, 158(1-3): 26-113.

Stehlin, H. G. (1909): Remarques sur les faunules de mammifères des couches éocènes et oligocènes du Bassin de Paris. - Bulletin de la Société Géologique de France, série 4, 9: 488-520.

Teilhard de Chardin, P. (1915): Les carnassiers des Phosphorites du Quercy. - Annales de Paléontologie, 9: 101192.

Tomiya, S., Tseng, Z. J. (2016): Whence the beardogs? Reappraisal of the Middle to Late Eocene 'Miacis' from Texas USA and the origin of Amphicyonidae (Mammalia, Carnivora). - Royal Society Open Science, 3: 160518 (25 pp.).

https://doi.org/10.1098/rsos.160518

Vianey-Liaud, M., Legendre, S. (1986): Les faunes des phosphorites du Quercy: principes méthodologiques en paléontologie des mammifères; homogénéité chronologique des gisements de mammifères fossiles. Eclogae geologicae Helvetiae, 79(3): 917-944.

Wesley-Hunt, G. D., Flynn, J. J. (2005): Phylogeny of the Carnivora: basal relationships among the carnivore morphans, and assessment of the position of 'Miacoidea' relative to Carnivora. - Journal of Systematic Palaeontology, 3(1): 1-28. https://doi.org/10.1017/S1477201904001518

Wesley-Hunt, G. D., Werdelin, L. (2005): Basicranial morphology and phylogenetic position of the upper Eocene carnivoremorphan Quercygale. - Acta Palaeontologica Polonica, 50(4): 837-846. 